University of Nebraska - Lincoln

DigitalCommons@University of Nebraska - Lincoln

\title{
Satellite-based herbaceous biomass estimates in the pastoral zone of Niger
}

\author{
Bruce K. Wylie \\ USGS EROS, wylie@usgs.gov \\ Issa Denda \\ New Mexico State University \\ Rex D. Pieper \\ New Mexico State University, rpieper@nmsu.edu \\ John A. Harrington Jr. \\ Kansas State University, jharrin@k-state.edu \\ Bradley C. Reed \\ New Mexico State University, reed@usgs.gov \\ See next page for additional authors
}

Follow this and additional works at: https://digitalcommons.unl.edu/usdaarsfacpub

Wylie, Bruce K.; Denda, Issa; Pieper, Rex D.; Harrington, John A. Jr.; Reed, Bradley C.; and Southward, G. Morris, "Satellite-based herbaceous biomass estimates in the pastoral zone of Niger" (1995). Publications from USDA-ARS / UNL Faculty. 1132.

https://digitalcommons.unl.edu/usdaarsfacpub/1132

This Article is brought to you for free and open access by the U.S. Department of Agriculture: Agricultural Research Service, Lincoln, Nebraska at DigitalCommons@University of Nebraska - Lincoln. It has been accepted for inclusion in Publications from USDA-ARS / UNL Faculty by an authorized administrator of DigitalCommons@University of Nebraska - Lincoln. 


\section{Authors}

Bruce K. Wylie, Issa Denda, Rex D. Pieper, John A. Harrington Jr., Bradley C. Reed, and G. Morris

Southward 


\title{
Satellite-based herbaceous biomass estimates in the pastoral zone of Niger
}

\author{
BRUCE K. WYLIE, ISSA DENDA, REX D. PIEPER, JOHN A. HARRINGTON, JR., \\ BRADLEY C. REED, AND G. MORRIS SOUTHWARD
}

\begin{abstract}
Authors are post doctoral fellow, USDA, ARS, Ft. Collins, Colo; graduate student, and professor, Department of Animal and Range Sciences., New Mexico State University, Las Cruces: associate professor, Department of Geography, Kansas State University, Manhattan, Kan; Earth Resources Observation Satellite Data Center, Sioux Falls, S.D.; and professor, Department Experimental Statistics, New Mexico State University, Las Cruces, N.M.
\end{abstract}

\begin{abstract}
Pastoralists in the Sahel of northern Africa are entirely dependent on their livestock, which graze on the annual vegetation produced during a relatively short summer rainfall season. The satellite-based normalized difference vegetation index, calibrated with ground-truth sampling of herbaceous biomass throughout the pastoral zone of Niger, was used to estimate standing biomass for the entire Nigerien pastoral zone. Data were obtained and analyzed during a 5-year period from 1986 through 1990. Techniques developed allow officials with the Government of Niger to estimate herbage available to support animal populations throughout the pastoral zone at the end of the growing season and plan grazing strategies for the impending dry season. End-of-season herbage standing crop varied from less than 200 $\mathrm{kg} \mathrm{ha}^{-1}$ to nearly $1,700 \mathrm{~kg} \mathrm{ha}^{-1}$ with locations and years. Strong biomass gradients were evident from mesic conditions in the southern pastoral zone to xeric conditions in the north.
\end{abstract}

Key Words: herbage standing crop, pastoralists, livestock grazing, geographic information systems

The African Sahel is an ecological zone on the southern edge of Sahara Desert. The rainfall pattern represents a unimodal distribution of monsoon origin, with most of the rains occurring from July to September. Average rainfall is low $(100 \mathrm{~mm})$ in the northern Sahel adjacent to the Sahara Desert while in the southern Sahel, adjacent to the Sudanian ecological zone, average rainfall may total up to $600 \mathrm{~mm}$ (Le Houerou 1980). Droughts are common in the Sahel and affect the livelihoods of many pastoralists and agriculturalists (Glantz 1987).

In Niger, a landlocked Sahelian country, United States Agency for International Development has supported the development of a national range assessment program. This range assessment program uses satellite images to extrapolate herbaceous biomass estimated from ground truth sites to the entire Nigerien pastoral zone. Rapid detection and quantification of drought extent and

Authors acknowledge helpful review by Dr. Bob Hass, Earth Resources Observation Satellite Data Center, Sioux Falls, S.D.

Contribution from the New Mexico Agr. Exp. Sta., Las Cruces.

Manuscript accepted 9 Jul. 1994. magnitude within the pastoral zone facilitate adjustments in national and international policies directed toward drought relief. The range assessment program also facilitates comparison among years and may encourage policies which take into account regional historical herbaceous biomass production levels. Such annual assessment is an important component of drought strategy (Wallen and Gwynne 1978). The objective of this paper is to demonstrate the utility of herbaceous biomass data within a geographic information system to assist policy and management decisions.

\section{Materials and Methods}

\section{Biomass Estimates}

The rangeland assessment system in Niger employed herbaceous biomass estimates from ground truth sites to calibrate the relationship between satellite-derived vegetation indices and herbaceous biomass (Wylie et al. 1992). The ground truth sites were selected to represent the major ecological communities mapped by Milligan (1982). In addition, ground truth sites also had to be accessible because they were sampled 2-4 times during the rainy season. The satellites used in this study were the National Oceanic Atmospheric Administration meteorological satellites, numbers 7,9 , and 11 . Since the field of view of these satellites is $1.2 \mathrm{~km}^{2}$, the ground truth sites initially were 10 by 10 km (1986-1987) as recommended by Wagenaar and De Ridder (1987). Biomass sampling site sizes were subsequently reduced to 5 by $5 \mathrm{~km}$ (1988) and 3 by $3 \mathrm{~km}$ (1989-1990). Ground truth site's size reductions were based on analysis using subsets of the biomass and satellite values from the larger ground truth stations used in 1986-1987 (Wylie 1991, Wylie et al.1992).

Herbaceous biomass estimates for the ground truth sites were obtained using a double sampling technique (Wilm et al. 1944, Bonham 1989). The number of estimated plot weights $\left(0.5 \mathrm{~m}^{2}\right)$ per ground truth site varied with ground truth site's size across years, ranging from 180 quadrats per ground truth site in 1987 to 60 per ground truth site in 1989 and 1990 . The percentage of quadrats clipped per ground truth site ranged from 10 to $14 \%$. Double sampling regression analysis used the weighted least squares technique. The location of quadrats within the ground truth site was determined using hierarchical randomization, except for 1986 when a $26 \mathrm{~km}$ zig-zag transect was used to strati- 
fy the ground truth sites into low, medium, and high biomass strata.

These polar orbiting satellites have the Advanced Very High Resolution Radiometer on board, which records radiance in the visible (primarily red and some green; channel 1), near infra-red (channel 2) and thermal infra-red wavelengths (channels 3-5). Because photosynthetically active pigments strongly absorb light in the red wavelengths and the mesophyll structure within leaves causes a high near infra-red reflectance, a number of vegetation indices utilizing the differences in red and near infra-red radiance have been created (Kauth and Thomas 1976, Jackson 1983). The normalized difference vegetation index (Townsend and Justice 1986) employed in this study is defined by the formula: normalized difference vegetation index $=($ infra-red - red $) /($ infra-red + red). Normalized difference vegetation index values associated with actively photosynthesizing vegetation range from 0.1 to 0.6 .

The National Oceanic Atmospheric Administration normalized difference vegetation index coverages for 1986-1988 were obtained from the National Aeronautical Space Administration Goddard Space Flight Center. Scientists in the Laboratory for Terrestrial Physics did the initial analysis of the data. Only satellite data within \pm 20 degrees of nadir were used. Thermal data (channel 4) were used to identify areas covered by clouds and these were replaced with zero values in the normalized difference vegetation index coverage (Holben 1986). National Oceanic Atmospheric Administration normalized difference vegetation index coverages for 1989 and 1990 were obtained from the receiving station at the Centre Regional de Formation et d' Application Agrometeorologie et Hydrologie Operationnelle office in Niamey, Niger. Cloud masking and selection of near nadir coverages were not performed on the 1989 and 1990 data. National Oceanic Atmospheric Administration normalized difference vegetation index coverages are available on a daily basis, but near nadir data were obtained on approximately $50 \%$ of the days (Harrington and Wylie 1989).

Maximum value composites are obtained by overlaying several normalized difference vegetation index coverages for successive dates in a raster geographic information system and retaining only the highest normalized difference vegetation index value for each pixel. Maximum normalized difference vegetation index values tend to be near nadir, have little or no cloud cover, and have minimal atmospheric contamination (Holben 1986, Harrington and Wylie 1989). The number of days associated with the normalized difference vegetation index coverages used to create the maximum value composite periods for 1986-1988 varied from 2 to 11 days as a function of available imagery and cloud contamination. For the 1989-1990 data obtained from the Centre Regional de Formation et d' Application Agrometeorologie et Hydrologie Operationnelle, maximum value composite periods were 10 days each.

The seasonally summarized normalized difference vegetation index statistic used in this study was the average integrated normalized difference vegetation index. Average integrated normalized difference vegetation index is a time-weighted daily normalized difference vegetation index average (Tucker et al. 1980). Each maximum value composite normalized difference vegetation index value is time-weighted by the number of days it represents such that the entire growing season, or integration periods, is accounted for. Depending on the data available each year, 9 or 10 maximum value composites were used to determine the average integrated normalized difference vegetation index.
Ground truth site herbaceous biomass estimates and average integrated normalized difference vegetation index values were used to develop equations for estimating herbaceous biomass for all pixels. Regressing average integrated normalized difference vegetation index for each ground truth site on September herbaceous biomass produced the linear model relating biomass in September (the end of the growing season) with the seasonally summarized satellite observations. Weighted least squares linear regressions were employed (Wylie 1991). Inverse predictions, which provide estimates of independent variables given dependent variable values (Neter et al. 1983), were used to convert satellite average integrated normalized difference vegetation index to herbaceous biomass.

\section{Determining the Extent of the Pastoral Zone Using a Geographic Information System}

Raster geographic information system functions were used to convert average integrated normalized difference vegetation index to biomass estimates for each year. Extrapolation of the average integrated normalized difference vegetation index and September biomass relationship to cover the entire pastoral zone was appropriate because ground truth sites were located throughout the region. However, extrapolation to the agricultural zone and the Sahara desert would be inappropriate because of the lack of ground truth sites in those regions. In addition, desert anomalies of normalized difference vegetation index associated with the Sahara (Holben 1986) and the incidence of cropland and higher percent coverages of trees in the agricultural zones make extrapolation of the pastoral average integrated normalized difference vegetation index to September biomass in these areas questionable. Delineation of the pastoral zone was thus necessary.

The southern limit of the pastoral zone was interpreted visually from Landsat thematic mapper images from 1986. This boundary is quite distinct because of the change in tone and texture associated with millet fields to the south of the southern boundary of the pastoral zone. The location of the boundary was transferred to a map of the whole country, digitized, and stored as a vector file. The northern limit was defined as areas having grazable forage at any year throughout the study period. Grazing trails conducted in Niger indicated that residual herbage levels after grazing of 250$350 \mathrm{~kg} \mathrm{ha}^{-1}$ were appropriate for heifers (Wylie et al. 1983). Grazable forage was thus defined as herbaceous biomass production greater than $350 \mathrm{~kg} \mathrm{ha}^{-1}$.

Satellite-derived estimates were used as inputs for a geographic information systems model which delineated the northern limit of the pastoral zone. Geographic information system masking techniques were used to restrict subsequent analysis and extrapolations to areas having greater than $350 \mathrm{~kg} \mathrm{ha}^{-1}$ biomass for any of the 5 years during the study. This, together with the vector southern boundary of the pastoral zone, resulted in a pastoral zone mask $(0=$ not in the pastoral zone and $1=$ within the pastoral zone).

\section{Carrying Capacity Estimates}

Geographic information system functions, polygon cutting, and statistics generation, were used to produce annual estimates of herbaceous biomass levels and hectarages for each pastoral zone department (or state) for areas within the pastoral zone (as defined above). Average herbaceous biomass for each department was used to calculate livestock carrying capacities. Carrying capacity estimates were based on a residual herbage level after 
grazing of $250 \mathrm{~kg} \mathrm{ha}^{-1}$. Pase (1985) found dry matter disappearance of herbaceous biomass without grazing to be about $4 \%$ a month in Niger. Dry matter disappearance for the 9 month dry season was accounted for before total available dry season forage was calculated. A daily dry matter disappearance rate of $7.5 \mathrm{~kg}$ $\mathrm{ha}^{-1}$ was attributed to one tropical livestock unit day, a $250 \mathrm{~kg}$ live weight equivalent. Total available dry season forage for each department among years was a function of the respective average herbaceous biomass and its associated surface area. However, expression of the carrying capacity in ha per tropical livestock unit was based on the size of the pastoral zone in each department.

Carrying capacity calculations assumed livestock grazing not to be limited by availability of drinking water. However, rangelands do exist where grazing is restricted by water availability, resulting in an overestimation of carrying capacities. The extent of such rangelands was unknown but was assumed to be negligible as Knight (1982) found water availability was not a major constraint for herd management in the pastoral zone of Niger.

\section{Classifying Nigerian Rangeland}

To effectively evaluate drought and to assist in national natural resource management decisions and policy identification, mapping of long-term range productivity classes would be useful. A multi-pass clustering algorithm, "interactive self-organizing data technique" (Earth Resources Data Acquisitions System 1990), was employed to divide the pastoral zone into 3 clusters based on recent biomass values. Classes identified using data from central Niger, where biomass estimates from 1986-1990 were available, were extrapolated to eastern and western Niger where estimates were only available for 1989-1990 using a maximum likelihood supervised classification.

\section{Results}

Regression statistics for average integrated normalized difference vegetation index regressed on September biomass are shown in Table 1. Weighted least squares analyses proved to be acceptable with the weighing factor being $1 /{\text { (September biomass })^{2}}^{2}$ (Wylie 1991, Wylie et al. 1991). The 1986 and 1987 ground truth site herbaceous biomass and average integrated normalized difference vegetation index data were pooled because ground truth site size was similar. The extra sum of squares principle indicated no significant difference in the slopes of different years or y intercepts from the 1986-1987 pooled regression. The 1989 regression had a low $r^{2}$ value and a relatively low standard error. This probably is in part due to the restricted range of September biomass associated with the ground truth sites in 1986 and the $r^{2}$ statistic's sensitivity to the range of the independent variable.

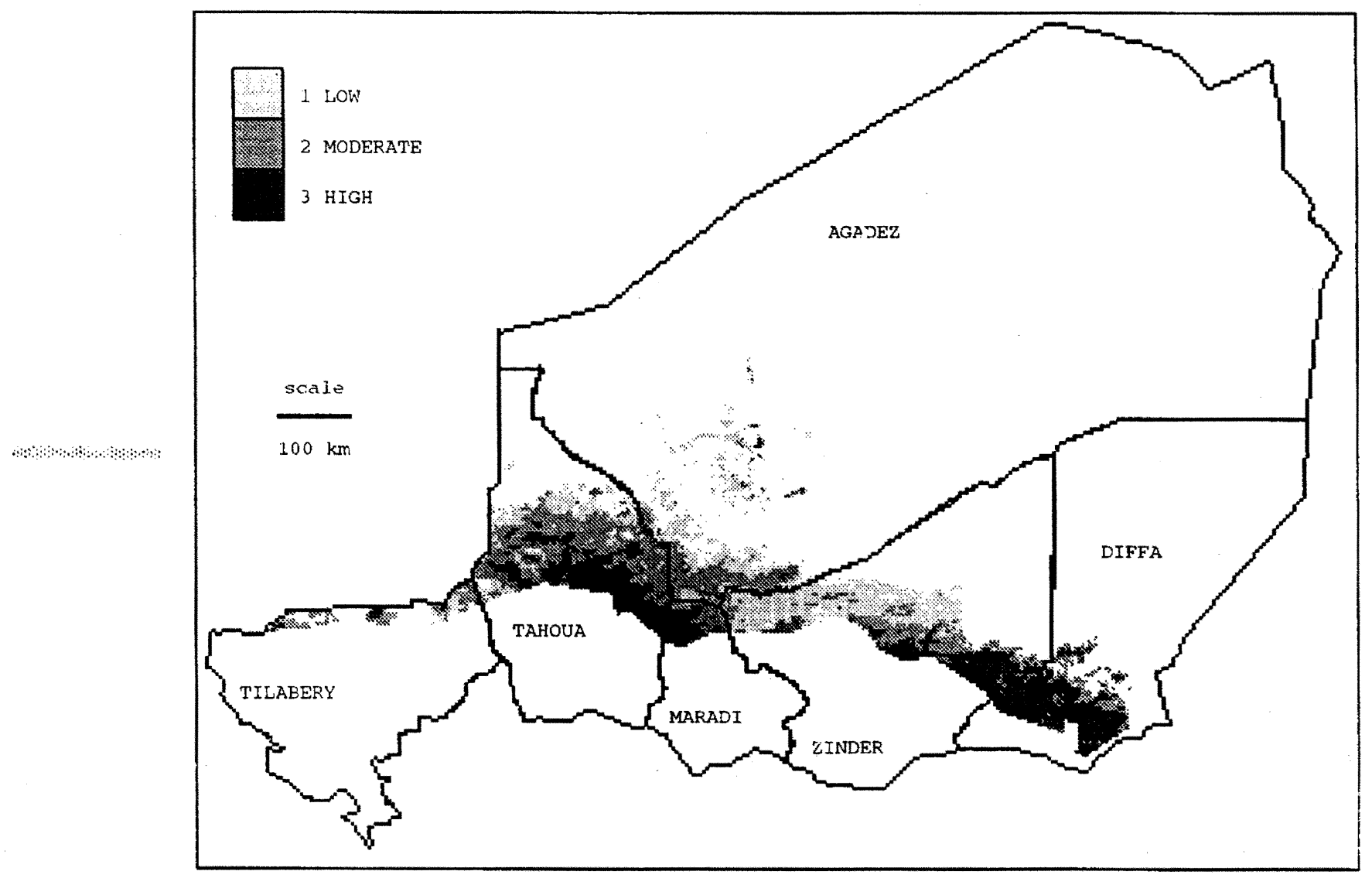

Fig. 1. Biomass classes within the pastoral zone of Niger based on 1986-1990 herbaceous biomass. 
Table 1. Statistics used to develop regression analysis showing relationship between normalized difference vegetation index and biomass, 1986-1990.

\begin{tabular}{lcccc}
\hline \hline Year & $\begin{array}{c}\text { No. ground } \\
\text { truth sites }\end{array}$ & $\begin{array}{c}\text { Ground truth } \\
\text { site size }\end{array}$ & $\mathrm{r}^{2}$ & $\begin{array}{c}\text { NDVI } \\
\text { S.E. }\end{array}$ \\
\hline & & $\left(\mathrm{km}^{2}\right)$ & & \\
$1986-87$ & 44 & 100 & 0.74 & 0.00003 \\
1988 & 29 & 30 & 0.80 & 0.00004 \\
1989 & 29 & 9 & 0.25 & 0.00003 \\
1990 & 29 & 9 & 0.67 & 0.00009 \\
\hline
\end{tabular}

'Weighted least squares standard error of normalized difference vegetation index.

Satellite coverages obtained for 1986-1988 were for central Niger and excluded the eastern and western portions of the country. Because 1986 and 1988 were favorable years, the eastern extent of the coverage is evident as a vertical line in the pastoral zone with the pastoral zone being much more restricted in the extreme east and west where data were only available for 19891990 (Fig. 1). Livestock production is not restricted to this pastoral zone delineation. This delineation, however, is a best estimate based on available data and includes areas where the bulk of dry season native forage is produced. The pastoral zone contains $134,663 \mathrm{~km}^{-2}$ of which the departments Tahoua, Zinder, and Tchirozerine contain the largest surface areas (Table 2).

Average pastoral herbaceous biomass available to grazing is presented in Table 3 for the study period. Due to the limited satellite coverages for 1986-1988, herbaceous biomass estimates could not be made for the entire pastoral zone of the Tilabery, Zinder, and Diffa departments. Higher average grazable herbaceous biomass and larger areas having grazable forage were associated with the favorable years 1986 and 1988 while lower values were associated with the drought years 1987 and 1990. The year 1989 was considered an intermediate year. Though the portion of the pastoral zone within the Maradi department was relatively small, it had high herbaceous biomass levels.

These data were used to calculate department annual carrying capacities (Table 4). The number of hectares needed to support one tropical livestock unit through the dry season was relatively low in the favorable years of 1986 and 1988 . Conversely the drought of 1987 and 1990 were evident in the large number of hectares needed to support one tropical livestock unit through the dry season. During drought years, long term dry season carrying capacities of over 100 ha per tropical livestock unit were observed in the Tilabery and Agadez departments. The estimated long-term carrying capacity of the southern, highly productive department of Maradi was only 6 ha per tropical livestock unit

Table 2. Size of each department in the pastoral zone of Niger.

\begin{tabular}{lrc}
\hline \hline Department & Size & Percent of total \\
\hline & $\left(\mathrm{km}^{2}\right)$ & $(\%)$ \\
Tilabery & 5,483 & 4 \\
Tahoua & 42,568 & 32 \\
Tchirozerine & 23,952 & 18 \\
Maradi & 5,617 & 4 \\
Zinder & 39,701 & 29 \\
Diffa & 17,341 & 13 \\
Pastoral zone & 134,663 & 100 \\
\hline
\end{tabular}

Table 3. Mean biomass estimates for departments (states) and arrondissements (counties) in the pastoral zone of Niger.

\begin{tabular}{|c|c|c|c|c|c|c|}
\hline \multirow[b]{2}{*}{ Department } & \multirow[b]{2}{*}{ Arrondissement } & \multicolumn{5}{|c|}{ Year } \\
\hline & & 1986 & 1987 & 1988 & 1989 & 1990 \\
\hline \multirow{3}{*}{ Diffa } & Diffa & & & $\mathrm{g} \mathrm{ha-1}^{-1}-$ & 936 & 880 \\
\hline & Maine & & & & 914 & 710 \\
\hline & Nguigmi & & & & 305 & 518 \\
\hline \multirow[t]{3}{*}{ Tilabery } & Filingue & & & & 325 & 290 \\
\hline & Quallan & & & & 592 & 274 \\
\hline & Tilabery & & & & 655 & 177 \\
\hline \multirow[t]{2}{*}{ Zinder } & Goure & & & & 344 & 391 \\
\hline & Tanout & 589 & 369 & 919 & 203 & 155 \\
\hline Agadex & Tchirozerin & 486 & 233 & 548 & 264 & 176 \\
\hline Maradi & Dakoro & 1,406 & 909 & 1,686 & 644 & 588 \\
\hline Tahoua & Tchin-Tabaraden & 695 & 283 & 830 & 673 & 383 \\
\hline \multirow{3}{*}{ Diffa } & Diffa & & & & 936 & 880 \\
\hline & Maine & & & & 914 & 710 \\
\hline & Nguigmi & & & & 305 & 518 \\
\hline \multirow[t]{3}{*}{ Tilabery } & Filingue & & & & 325 & 290 \\
\hline & Quallan & & & & 592 & 274 \\
\hline & Tilabery & & & & 655 & 177 \\
\hline \multirow[t]{2}{*}{ Zinder } & Goure & & & & 344 & 391 \\
\hline & Tanout & 589 & 369 & 919 & 203 & 155 \\
\hline Agadex & Tchirozerin & 486 & 233 & 548 & 264 & 176 \\
\hline Maradi & Dakoro & 1,406 & 909 & 1,686 & 644 & 588 \\
\hline Tahoua & Tchin-Tabaraden & 695 & 283 & 830 & 673 & 383 \\
\hline
\end{tabular}

(Table 5). The average long term carrying capacity for the entire pastoral zone was 23 ha per tropical livestock unit or nearly 600,000 tropical livestock units. Departments with the largest interannual average dry season carrying capacity were Tahoua, Diffa, Zinder, and Maradi.

Stocking rate estimates for 1988 for the arrondissements (counties) within the departments of the pastoral zone, obtained from an annual report of the Ministry of Agriculture and Livestock, Niamey, Niger, were totaled by department (state) and presented in Table 5. The semi-nomadic movements of pastoralists complicate comparisons between carrying capacities and stocking rates. The bulk of the pastoralists leave the pastoral zone with their herds once the croplands in the agricultural zone have been harvested. Indeed, pastoralist movements often cross national boundaries and may contribute to high rainy season and early dry season stocking rates, particularly in the Diffa, Zinder, and Tilabery departments. In addition, stocking rate estimates for entire arrondissements include livestock within the agricultural zone while carrying capacity calculations were restricted the pastoral zone. Better estimates of dry season stocking rates within the pas-

Table 4. Annual carrying capacity estimates for departments of the pastoral zone of Niger.

\begin{tabular}{lrrrrr}
\hline \hline & \multicolumn{5}{c}{ Years } \\
\cline { 2 - 6 } Department & 1986 & 1987 & 1988 & 1989 & 1990 \\
\hline & -198 & & \\
Tilabery & 8 & 45 & 6 & 19 & 148 \\
Tahoua & 15 & 102 & 14 & 45 & 408 \\
Tchirozerine & 3 & 5 & 2 & 9 & 12 \\
Maradi & & & & 32 & 38 \\
Zinder & & & & 10 & 12 \\
Diffa & & & &
\end{tabular}


Table 5. Estimated ling-term carrying capacity and 1988 stocking rate by department in the pastoral zone of Niger.

\begin{tabular}{lccr}
\hline \hline Department & Long-term average carrying capacity & Stocking rate \\
\hline & (ha tropical livestock unit) & \multicolumn{1}{c}{----(tropical livestock units)----- } \\
Tahoua & 21 & 207,087 & 370,802 \\
Diffa & 11 & 158,271 & $1,195,239$ \\
Zinder & 35 & 113,855 & 526,019 \\
Maradi & 6 & 88,483 & 39,466 \\
Tchirozerine & 117 & 20,509 & 58,992 \\
Tilabery & 83 & 6,575 & 319,644 \\
Total & & 594,780 & $2,510,162$ \\
\hline
\end{tabular}

toral zone are needed. Of the 1988 tropical livestock units within the pastoral arrondissements, we estimated that $80 \%$ would be in the pastoral zone during the rainy season, the remaining $20 \%$ being milk produced animals and animals used in animals traction for sedentary agriculturalists. During the 2 month post rainy season period, October-November, $60 \%$ of the livestock in the pastoral zone were expected to return to the agricultural zone. During the 7 month period from December-June, only $20 \%$ of the livestock present during the rainy season were expected to remain in the pastoral zone, the other animals moving into the agricultural croplands after sorghum had been harvested in December and pastoralists were no longer liable for their animals damaging crops. Using this crude model, average 1988 dry season stocking rate for the pastoral zone was 580,126 tropical livestock units and was similar to the long term average dry season carrying capacity for the pastoral zone.

Three long-term range production classes were identified and mapped using the interactive self-organizing data analysis technique that took into account the spatial variation in herbaceous biomass from 1986-1990 (Fig. 1). Biomass class 1 seems to be poorly represented in the extreme eastern and western Niger where only 1989 and 1990 biomass estimates were available. However, given the continuity of biomass classes 2 and 3 across the satellite data limitation boundaries, the lack of biomass class 1 in eastern and western Niger may be attributed to the lack of herbaceous biomass estimates in the favorable years 1986 and 1988. Table 6 shows yearly mean biomass averages for each biomass class. Class 1 , which made up $32 \%$ of the pastoral zone, represents rangelands having low biomass production potential Class 2 made up $37 \%$ of the pastoral zone and represents range-

Table 6. Herbaceous biomass yearly means within biomass classes and their respective standard deviations (sd) for the pastoral zone of Niger.

\begin{tabular}{lccccc}
\hline \hline & \multicolumn{5}{c}{ Year } \\
\cline { 2 - 6 } & 1986 & 1987 & 1988 & 1989 & 1990 \\
\hline Class 1 & & & & & \\
Mean (kg ha-1) & 378 & 153 & 456 & 179 & 174 \\
sd & 183 & 130 & 232 & 174 & 124 \\
Class 2 & & & & & \\
Mean (kg ha $\left.{ }^{-1}\right)$ & 670 & 294 & 835 & 494 & 304 \\
sd & 222 & 193 & 262 & 265 & 152 \\
& & & & & \\
Class 3 & & & & & \\
Mean (kg ha-1) & 1,170 & 683 & 1,489 & 949 & 553 \\
sd & 403 & 316 & 374 & 384 & 209 \\
\hline
\end{tabular}

lands with intermediate herbaceous biomass production potentials. Class 3 made up $31 \%$ of the pastoral zone and represents rangelands with high herbaceous biomass production potentials. Evident in all 3 biomass classes are the higher herbaceous biomass means associated with the favorable years 1986 and 1988 as well as the lower herbaceous biomass means associated with the drought years 1987 and 1990.

\section{Conclusions}

Carrying capacity estimates based on correlations with Advance Very High Resolution Radiometer satellite data with ground truth sites appear to be reasonably reliable, with the long term dry season pastoral zone carrying capacity estimated to be 23 ha per tropical livestock unit. The delineation of the pastoral zones appears representative and confines the use of the relationship between average integrated normalized difference vegetation index and herbaceous biomass to areas within the pastoral zone. Stocking rate estimations should be refined to better reflect the dynamics of the dry season pastoral zone stocking levels.

Identification of rangeland production potentials will assist in drought monitoring and management of natural resources. The grazing strategies of the pastoralists allow them to deal with annual droughts, but when droughts occur for 2 or more successive years the results are catastrophic (Sollod 1990). As the human population and the animals needed to support them expand, flexibility of moving to ungrazed areas decreases and the effects of extended drought become less manageable.

Knowledge of the extent and location of areas with high production potentials is important to policy-decision makers. Productive rangelands pose a fire danger in the early dry season. Productive rangelands also may be considered for possible hay or silage production and may have potential for dryland agriculture whereas an extension of dryland agriculture into marginal rangelands (biomass classes 1 and 2) should be discouraged. Productive areas could possibly serve as drought indicator areas. If vegetation phenology and growth are retarded in these regions, other drought monitoring and possible preliminary drought interventions might be considered.

\section{Literature Cited}

Bonham, C.D. 1989. Measurements for terrestrial vegetation. John Wiley and Sons. New York, N.Y.

Earth Resources Data Acquisitions Systems. 1990. Field Guide, Version 7.4. Earth Resource Data Acquisitions System, Atlanta, Ga.

Glantz, M.H. 1987. Drought in Africa. Sci. Amer. 256:34-40.

Harrington, J.A., Jr., and B.K. Wylie. 1989. Assessing annual changes in the Sahelian vegetation of Niger. Papers and Proc. Applied Geography Conf. 12:107-115.

Holben, B.N. 1986. Characteristics of maximum-value composite images from temporal AVHRR data. Int. J. Remote Sensing 7:1417-1434.

Jackson, R.D. 1983. Spectral indices in n-space. Remote Sensing Environ. 13:409-421.

Kauth, R.J. and G.S. Thomas. 1976. The tassel cap-a graphic description of the spectral-temporal development of agricultural crops as seen by Landsat. Proc. Symp. Machine Processing Remotely Sensed Data, Institute of Electrical and Electronics Engineers Catalogue No. 76, Ann Arbor, Mich.

Knight, J. 1982. NRL water point survey final report. Niger Range and Livestock Project. U.S. Agency for Inter. Devel., Tahoua, Niger.

Le Houerou, N.H. 1980. The rangelands of the Sahel. J. Range Manage. 
33:41-46.

Milligan, K. 1982. Aerial survey of human, livestock and environmental conditions in a central regions of the pastoral zone of Niger. Final Report for U.S. Agency for Internat. Devel./Niger. Internat. Livestock Centre for Africa. Kaduna, Nigeria.

Neter, J., W. Wasserman, and M.H. Kutner. 1983. Applied linear regression models. Richard D. Irwin, Homewood, Ill.

Pase, C.P. 1985. Early warning system 1985 report. Niger Integrated Livestock Production Project. U.S. Agency for Internat. Devel., Tahoua Niger.

Sollod, A.E. 1990. Rainfall, biomass and the pastoral economy of Niger: assessing the impact of drought. J. Arid Environ. 18:97-100.

Townsend, J.R.G., and C.O. Justice. 1986. Analysis of the dynamics of African vegetation using the normalized difference vegetation index. Internat. J. Remote Sensing 46:657-666.

Tucker, C.J., B.N. Holben, J.H. Elgin, Jr., and J.E. McMurtrey III. 1980. Relationship of spectral data to grain yield variation. Photogram. Eng. Remote Sensing 46:657-666.
Wagenaar, K.T., and N. DeRidder. 1987. Estimates of biomass production and distribution in the ILP project zone in 1985 based on satellite normalized difference vegetation index values. Internat. Livestock Centre for Africa. Plant Sci. Div. Working Paper No. C1, Addis Ababa, Ethiopia.

Wallen, C.C., and M.D. Gwynne. 1978. Drought-a challenge to range land management, p. 21-31. In: D.N. Hyder (ed.), Proc. First Inter. Rangeland Congress, Soc. Range Manage., Denver, Colo.

Wilm, H.G., D.I. Costello, and G.E. Klipple. 1944. Estimating forage yield by the double sampling method. J. Amer. Soc. Agron. 36:194-203.

Wylie, B.K. 1991. Herbaceous biomass assessment in the central pastora zone of the Sahelian country of Niger 1986-1988. Ph.D. Diss., New Mexico State University, Las Cruces, N.M.

Wylie, B.K., J.A. Harrington, Jr., R.D. Pieper, and I. Denda. 1992. A satellite based range assessment system for the Sahel of Africa. Geocarto Internat. 7:79-85.

Wylie, B., R. Senock, L. Snyder, B. Roettgen, and B. Porter. 1983. Niger range and livestock project: range research and results. Niger Range and Livestock Project, U.S. Agency for Inter. Devel., Tahoua, Niger. 